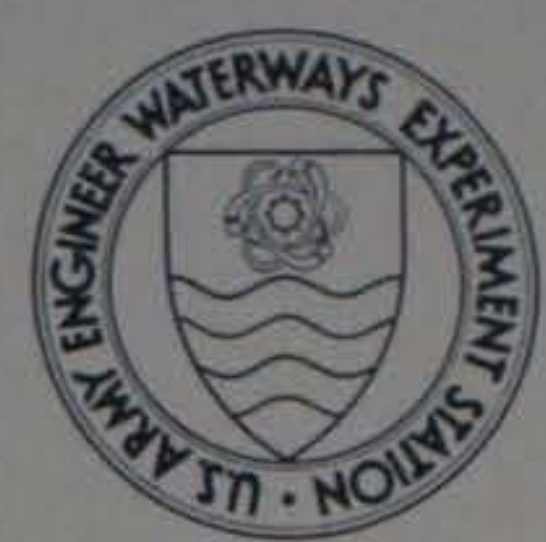

\title{
PREDICTIONS OF THE AIRBLAST AND GROUND MOTIONS RESULTING FROM EXPLOSIVE REMOVAL OF THE BIRDS POINT-NEW MADRID. FUZE PLUG LEVEE
}

by

James L. Drake, Leo F. Ingram

Structures Laboratory

U. S. Army Engineer Waterways Experiment Station

P. O. Box 631, Vicksburg, Miss. 39180

November 1981

Final Report

Approved For Public Release; Distribution Unlimited

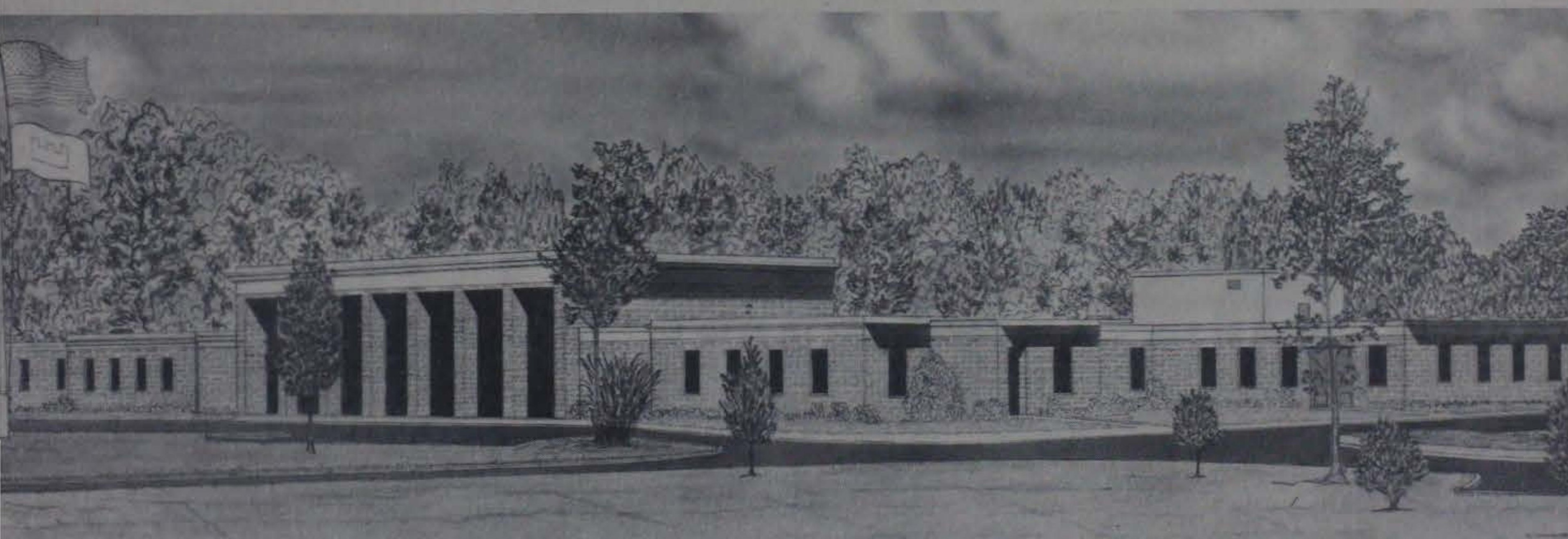

Prepared for U. S. Army Engineer District, Memphis Memphis, Tenn. 38103

LIBRARY BRANCH TECHNICAL INFORMATION CENTER 
1. REPORT NUMBER

REPORT DOCUMENTATION PAGE

Miscellaneous Paper SL-81-30

4. TITLE (and Subtitie)

PREDICTIONS OF THE AIRBLAST AND GROUND MOTIONS RESULTING FROM EXPLOSIVE REMOVAL OF THE BIRDS POINT-NEW MADRID FUZE PLUG LEVEE

7. AUTHOR(a)

James L. Drake

READ INSTRUCTIONS BEFORE COMPLETING FORM

Leo F. Ingram

9. PERFORMING ORGANIZATION NAME AND ADDRESS

U. S. Army Engineer Waterways Experiment Station

Structures Laboratory

P. 0. Box 631, Vicksburg, Miss. 39180

11. CONTROLLING OFFICE NAME AND ADDRESS

U. S. Army Engineer District, Memphis

668 Clifford Davis Federal Building

Memphis, Tenn. 38103

14. MONITORING AGENCY NAME \& ADDRESS(If difforent from Controlling Offlco)

5. TYPE OF REPORT \& PERIOD COVERED

Final report

6. PERFORMING ORG. REPORT NUMBER

8. CONTRACT OR GRANT NUMBER(A)

10. PROGRAM ELEMENT, PROJECT, TASK AREA \& WORK UNIT NUMBERS

3. RECIPIENT'S CATALOG NUMBER

2. REPORT DATE

November 1981

13. NUMBER OF PAGES

23

15. SECURITY CLASS. (of this roport)

Unclassified

15a. DECLASSIFICATION/DOWNGRADING
SCHEDULE

16. DISTRIBUTION STATEMENT (of this Roport)

Approved for public release; distribution unlimited.

17. DISTRIBUTION STATEMENT (of the abstract ontered in Block 20, if difforent from Report)

18. SUPPLEMENTARY NOTES

Available from National Technical Information Service, 5285 Port Royal Road, Springfield, Va. 22151.

19. KEY WORDS (Continue on reverse side if necessary and Identify by block number)
Air blast waves
Levees
Explosion effects
Slurry explosions

Ground motion

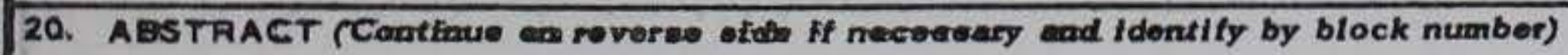

Emergency flood procedures call for the creation of two large crevasses in the Birds Point-New Madrid fuze plug levee on the Mississippi River below Cairo, I11.

Slurry explosives will be used to create $11,400-$ and $6000-\mathrm{ft}$ breaches in the levee system. Potential hazards to nearby structures from airblast and ground shock from these explosions (128 and 67 tons, respectively) were assessed.

(Continued) 


\section{ABSTRACT (Continued)}

Conventional methods could not be used to predict explusion effects because of (a) the unusual geometry of the explosion and (b) most civil blasting safety procedures were developed for rock. A data base from row charge experiments in soil was analyzed for this project.

As a result of this study, it is believed that:

a. No structural damage should be expected at distances greater than $1800 \mathrm{ft}$ from either levee section.

b. An isolated ejecta clod is possible but not probable at distances of $2500 \mathrm{ft}$.

c. Safe limits will be the same for both crevasses, depending only on the linear loading density of the explosive ( $1 \mathrm{~b} / \mathrm{ft}$ of levee).

d. Although residents of Wickliffe, Ky., may hear the airblast and feel the ground vibrations, no window or structural damage should be expected there.

e. Cairo, I11., will not be affected. No complaints are anticipated. 
This report presents an assessment of the airblast and ground motion hazards for explosively creating breaches in the Birds Point-New Madrid fuze plug levee on the Mississippi River below Cairo, Illinois. This assessment was conducted for the Memphis District, CE, under IntraArmy Order 81-22 dated 2 July 1981.

Messrs. Jim Drake and Leo Ingram of the Explosion Effects Division of the Structures Laboratory conducted the study and authored this report. 
CONVERSION FACTORS, U.S. CUSTOMARY TO METRIC (SI)

UNITS OF MEASUREMENT. ................. 3

PART I: INTRODUCTION ....................... 4

Background .................... 4

Problem Statement. ............... 4

Approach ................ 5

PART II: EXPLOSION HAZARDS ................ 9

Airblast Hazards . . . . . . . . . . . . . 9

Ground Shock Hazards .................. 9

Ejecta Hazard. . . . . . . . . . . . . . . . 11

PART III: EXPLOSION EFFECTS ESTIMATES. . . . . . . . . 14

General. . . . . . . . . . . . . . . 14

Airblast Effects . . . . . . . . . . . . . . 14

Ground Motions . . . . . . . . . . . . . . 17

Ejecta........................ 20

PART IV: SUMMARY AND CONCLUSIONS ............. 21

Limits of Damage to Structure. . . . . . . . . . . 21

Effects at Wickliffe, Kentucky .............. 21

Effects at Cairo, Illinois . . . . . . . . . . . 21

Conclusions................. 22

REFERENCES. . . . . . . . . . . . . . . 23 
U.S. customary units of measurement used in this report can be converted to metric (SI) units as follows:

\begin{tabular}{|c|c|c|}
\hline Multiply & By & To Obtain \\
\hline inches & 2.54 & centimetres \\
\hline feet & 0.3048 & metres \\
\hline $\begin{array}{l}\text { pounds (force } \\
\text { per square inch }\end{array}$ & 6.894757 & kilopascals \\
\hline $\begin{array}{l}\text { pounds (force } \\
\text { per square inch }\end{array}$ & 69.0 & mbar \\
\hline inches per second & 2.54 & $\begin{array}{l}\text { centimetres per } \\
\text { second }\end{array}$ \\
\hline pounds (mass) & 0.4535924 & kilograms \\
\hline miles & 1.609344 & kilometres \\
\hline
\end{tabular}




\section{PREDICTIONS OF THE AIRBLAST AND GROUND MOTIONS \\ RESULTING FROM EXPLOSIVE REMOVAL OF THE \\ BIRDS POINT-NEW MADRID FUZE PLUG LEVEE}

\section{PART I: INTRODUCTION}

\section{Background}

1. The December 1979 draft of the Emergency Operations Plan (EOP) (Reference 1) describes in detail the procedure for explosively creating breaches in the Birds Point-New Madrid fuze plug levee on the Mississippi River below Cairo, Illinois. Creation of two large crevasses would use an estimated 128 and 67 tons of explosive slurry along 11,400- and 6,000-ft sections of the levee system, respectively. Airblast and ground motions produced by the detonation of large quantities of explosives pose a potential hazard to nearby structures. The objective of this report is to assess these hazards and to estimate distances from the explosions where no appreciable damage would be expected.

\section{Problem Statement}

2. The EOP describes in detail the operations including explosive amounts and configurations to be used to create the crevasses. Briefly, two crevasses are planned: No. 1 is $11,400 \mathrm{ft}$ long and No. 2 is 6,000 ft long. The explosive plan is nearly the same for each crevasse--three parallel lines of explosive charges spaced $12 \mathrm{ft}$ apart, running the length of each crevasse. Holes containing $120 \mathrm{lb}$ of aluminized slurry explosive will be placed at 16-ft intervals along each line, providing about $22.5 \mathrm{lb}$ of explosive per lineal foot of crevasse. Thus, approximately 128 tons of slurry will be used on Crevasse No. 1 and about 67 tons is planned for Crevasse No. 2. Demolition of the crevasses will not be simultaneous.

3. Initiation of individual charges will be by explosive detonation cord (trade named Primacord). The Primacord will be placed in a loop above the ground to provide redundancy in the initiation chain. Because the Primacord detonates at a velocity of about 22,000 ft/sec, it 
will take approximately one-half second to detonate the entire $11,400-\mathrm{ft}$ row of charges in Crevasse No. 1. There will be no deliberate attempt to delay detonation of the individual charges. The area surrounding the levee system is sparsely populated farmland within the floodway to the southwest (See Figure 1). The nearest population center of concern is Wickliffe, Kentucky, which is located across the Mississippi River northeast of Crevasse No. 1 at a distance of about $8700 \mathrm{ft}$. Cairo, Illinois, is located about three miles north of Crevasse No. 1 and should not be affected by the explosion.

Approach

4. Because of the complexity of the explosive source--multiple charges in a row with non-simultaneous detonations--there are no known methods to calculate the long range blast and shock effects from first principle approaches. Therefore, our approach is to use data collected on past explosion tests--both single burst and row charge events--scaled to fit this situation. In most cases, upper bounds of these data were used to provide conservative estimates of the potential hazards.

5. The problem of detonating nearly simultaneous row charges in very large quantities in soil is unusual to both civil construction and industrial applications. Most civil blasting is in rock such as mining, quarry operations, or construction excavation and is normally detonated in delayed sequences to reduce the ground shock vibrations. For rock blasting a large body of literature is devoted to blasting safety and the development of criteria for blasting damage to structures. No literature was found for civil blasting applications in soils.

6. A data base for buried explosions in soil had to be developed for the current problem to provide estimates of the airblast and ground shock hazard. Most large scale buried bursts in soil are from Department of Defense simulations of the effects of buried nuclear explosions. Principal sources of single burst data include the ESSEX* and Diamond Ore series of 10-ton to 40-ton explosions in soil and shale, respectively. Ground motions from row charges were assessed from the MEACE**

\footnotetext{
* Effects of Subsurface Explosives

** Military Engineering Application of Commercial Explosives
} 


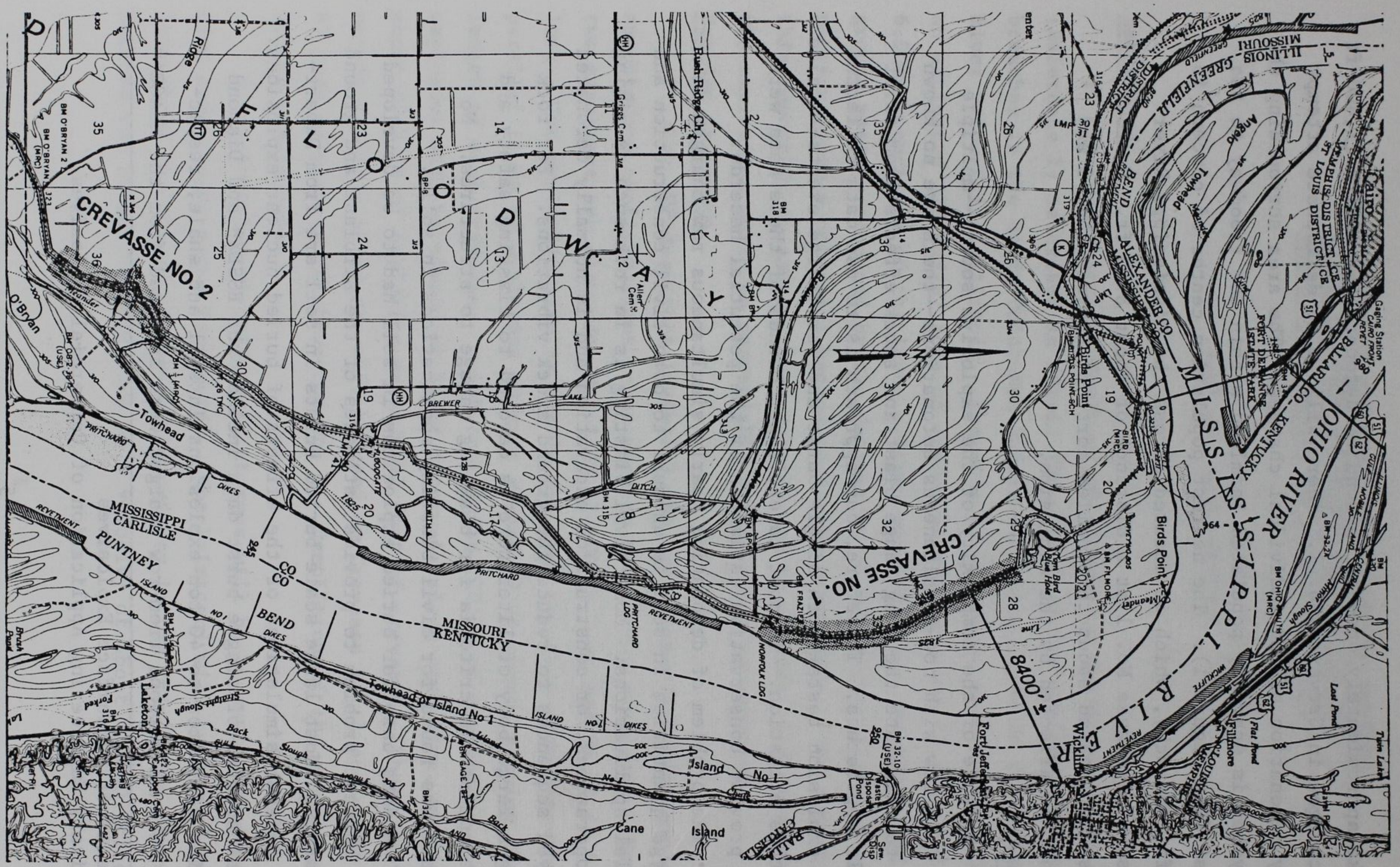

Figure 1. Vicinity map, Birds Point - New Madrid Floodway. 
and related row cratering experiments; the airblast from buried row charges was developed from Plowshare test data.

7. Factors that influence the strength of airblast and ground shock from buried cratering row charges include: soil properties (primarily saturation) depth-of-burial, degree of stemming, local geology and geometric relationships of the target point to the charge.

a. Soil Properties. In general peak particle velocity (a damage index) is lower for explosions in soil than in rock. Wet soils can produce high accelerations and generally exhibit higher particle velocities. Vibration periods of ground motions in soils are much lower than in rock, thus resulting in larger particle displacements near the charge. Ground motion frequencies are typically proportional to the shear wave velocity in the geologic medium.

b. Depth-of-Burial. Ground shock increases rapidly with increase in depth of burial until the explosion is near optimum depth of burst for cratering where it becomes essentially fully tamped. Airblast is quickly suppressed by increasing depth of burial. Shallow bursts produce a strong gas-venting airblast wave. Deeper bursts produce an airblast pulse from sudden upward movement of the ground and a later pulse from venting of the explosion products. For optimum cratering depths, these pulses are of comparable amplitude.

c. Stemming. The degree of stemming (or backfill) strongly influences the airblast produced by the venting explosion products. Ground shock is not strongly affected by stemming for cratering bursts.

d. Local Geology. Strong geologic interfaces between the explosion source and the structure influence the frequency of the ground motion. Shallow depths to rock will produce higher frequency motions, while deep rock layers will result in low frequency particle motions.

e. Charge Geometry. Geometrical spreading of the blast wave and ground motion accounts for much of the attenuation of these effects at increasing distances from the explosion.

(1) Line Charge. Energy from a line charge is distributed initially on the surface of a cylinder. For this case, the energy must be expressed as the charge weight per unit length, $w$, of the line. Thus, near a long row charge (within one charge length), the amplitude of the airblast and ground motion depends on the linear charge density, $w$, and not the 
total charge weight. In this region, attenuation of effects is much less rapid than for point source explosions and should scale proportional to (w) ${ }^{1 / 2}$.

(2) Concentrated Charge. Energy from a concentrated burst is distributed initially on the surface of a sphere. At distances greater than the length of a line charge, propagation becomes more and more spherical and the total charge weight, $W$, must be used to evaluate the potential hazards. Effects in this region scale proportional to $(\mathrm{W})^{1 / 3}$.

8. For our problem, the population center of Wickliffe, Kentucky, is near the transition point from the cylindrical to spherical propagation region. The available data were separated into these regions and both methods were applied to provide bounds on the resulting effects. 


\section{Airblast Hazards}

9. Windows are more susceptible to damage from airblast than other structural components; hence we will base our airblast damage criterion on them. Because of the differences in the strength of the glass, window size, frame and glazing conditions, etc., it is impossible to determine a single damage threshold pressure level for all windows. The orientation of the window with respect to the explosion also has a significant effect.

10. Reed (Reference 2) has conducted extensive analyses of airblast propagation and window damage from both controlled explosive tests and accidental explosions. Figure 2, adapted from Reed, shows the probability of window damage based on controlled tests by the Pittsburgh Plate Glass Company and from an accidental explosion near Medina, TX. Reed considers $0.06 \mathrm{psi}$ as the threshold for breaking very large windows with long duration blast waves (from nuclear tests in Nevada). This produces a probability of damage of $3 \times 10^{-5}$. The U.S. Bureau of Mines (Reference 5) indicates that a blast pressure level of $0.5 \mathrm{psi}$ is acceptable on windows. The probability of damage at this level is 6 out of 100 windows. While we consider Reed's threshold to be conservative, we believe the risk associated with the U.S. Bureau of Mines threshold to be excessive. If we could predict blast pressure levels with little uncertainty, we would opt for a damage probabality of one in one thousand; this occurs at a pressure level of about 0.145 psi. Since atmospheric conditions (notably unfavorable winds and temperature inversions) can increase blast propagation markedly; these are unpredictable. Thus, it is recommended that Reed's threshold ( $0.06 \mathrm{psi})$ be used as the design upper limit of exposure for this operation.

Ground Shock Hazards

11. Rational damage criteria for blasting vibrations cannot be defined by a single measure of ground motion. Several factors influence the response of structures and their susceptibility to damage including type of construction, number of stories, soil and foundation conditions 


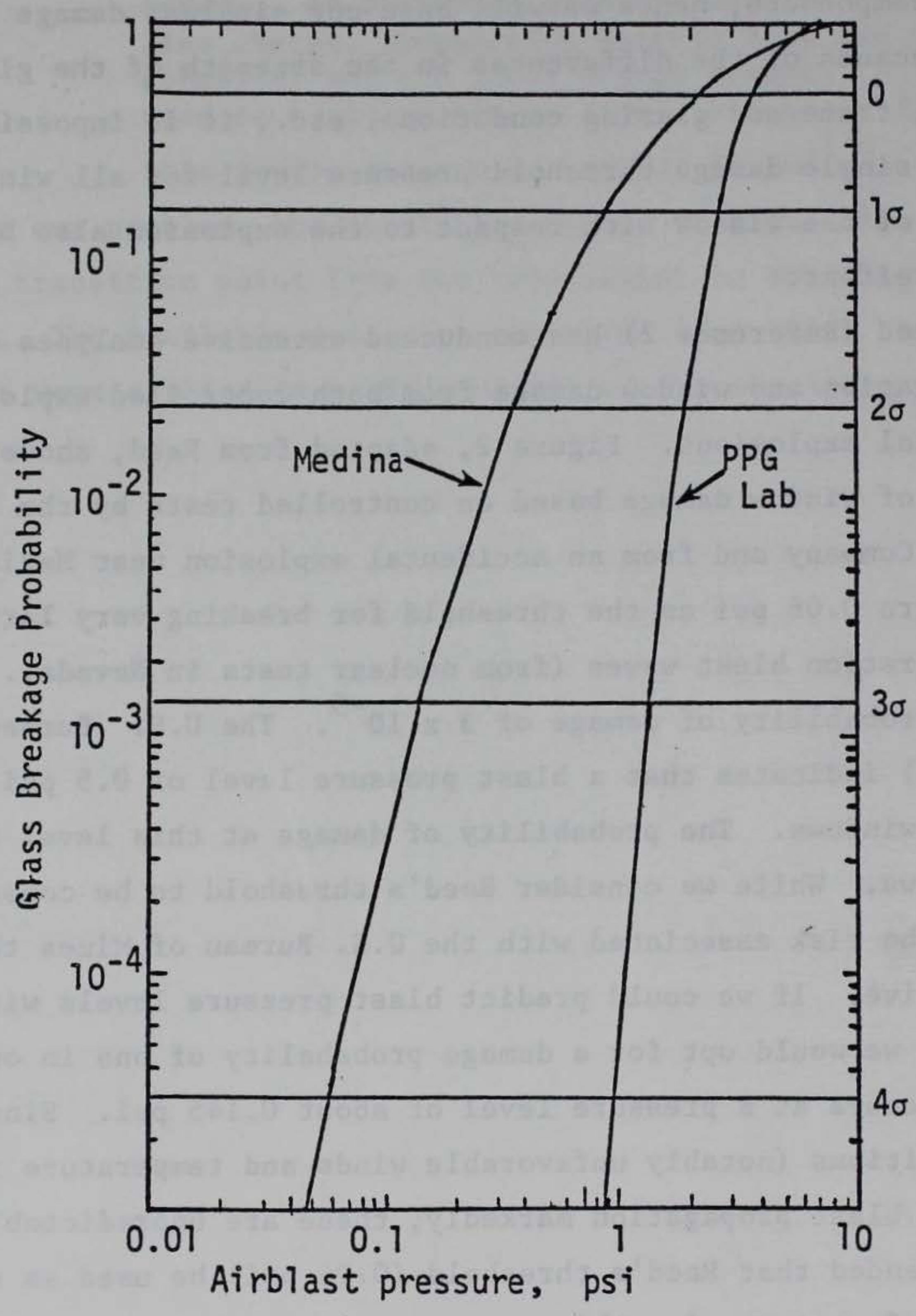

Figure 2. Lognormal probabilities of glass breakage versus applied pressure (after Reed, Reference 2) 
and age of the structure, to name only a few. Acceptable damage may also depend on the use of the structure, i.e., motions that crack plaster in a residence may be acceptable for commercial buildings with suspended ceilings. Most complaints associated with blasting involve relatively minor items such as hairline cracks in masonry walls, stucco, gypsum wallboard, plaster, and occasional window breakage. Failure or even potential failure of the primary structure is usually not a problem. 12. In 1949, Crandel1 (Reference 3) first suggested a measure for safe blasting levels. He found that the energy ratio (ER), defined as the square of the ratio of maximum acceleration in feet per second squared to frequency in Hertz, could be correlated with damage. In a study of over 1000 structures, he found that an ER of 3 or below was safe, and that the danger of producing damage was high for an ER of 6 or greater. For harmonic motion, an ER of 3 to 6 corresponds to maximum particle velocities of 3.3 to $4.7 \mathrm{in./sec,} \mathrm{respectively.} \mathrm{Other} \mathrm{studies}$ have led to similar conclusions.

13. Several states have adopted or are adopting a maximum peak particle velocity such as $2 \mathrm{in./sec} \mathrm{as} \mathrm{a} \mathrm{legal} \mathrm{damage} \mathrm{criterion.} \mathrm{A} \mathrm{peak}$ particle velocity maximum of $2 \mathrm{in./sec}$ has been adopted by the Corps of Engineers (Reference 4), throughout the blasting industry, government and in the literature (References 5 thru 7) as the de facto threshold damage criterion, and is therefore used for this study.

14. One aspect that should not be overlooked is the human response to the blast induced vibrations. Hendron (Reference 7) points out that people can notice transient motions as $10 \mathrm{w}$ as $0.06 \mathrm{in} / \mathrm{sec}$. Motions can become disturbing at $0.4 \mathrm{in.} / \mathrm{sec}$, much less than levels that could cause damage to structures. If the explosion is accompanied by an audible airblast, the loud noise is sufficient to prove severity and cause complaints, even at low particle velocity levels of $0.2 \mathrm{in./sec}$. Figure 3 is a simplified guideline for human response to blasting vibrations. Ejecta Hazard

15. A large amount of soil will be blown from the vicinity of the explosion to form the crater for the crevasse. Most of this material 

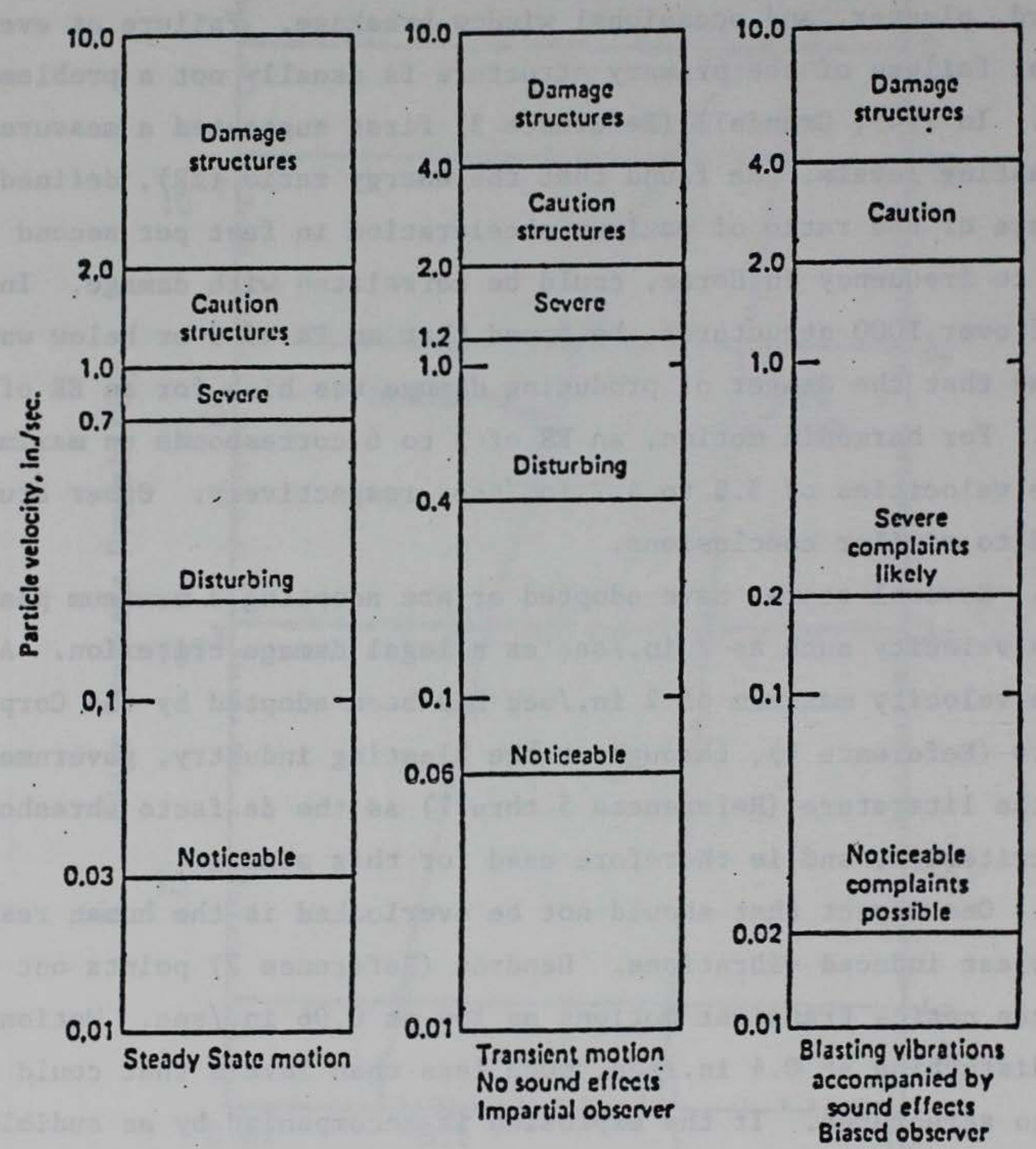

Figure 3. Human response to vibrations (after Hendron, Reference 7). 
will fall back into a region within a few crater radii from the line of detonation. The areal density of this material decreases rapidly with increasing distance from the explosion. However, some soil clods may be ejected to considerable ranges from the explosion and could pose a hazard to personal safety.

16. Limited data obtained recently on antitank ditching demonstrations conducted by WES may be used to estimate this hazard. These tests indicate that some ejecta may travel as far as $1500 \mathrm{ft}$ with a very low probability that a clod may extend to $2300 \mathrm{ft}$ for the loading densities considered in this study. While the probability that a given area will experience ejecta clods is remote at these ranges, some ejecta within 1500 and $2500 \mathrm{ft}$ from the explosion is possible. 
General

17. Peak ground motions and airblast estimates are developed in this section from empirical data collected from buried single charge explosions and from limited testing of row charge explosions in soil. Because the crevasses are extremely long, the safe zone for structures will lie in the cylindrical propagation region of the explosion. Thus, estimates for safe limits of airblast and ground motion will depend on the linear loading density and will not be dependent on the length of the crevasse or the total charge detonated.

Airblast Effects

18. The data base for airblast from buried line charges is limited to testing conducted in the 1960's for the Plowshare Program by Sandia Laboratories (as reported by Vortman (Reference 8)). In these tests, 64-1b buried charges were detonated at 6.0- and 6.9-ft depth of burial in rows of 2 to 25 charges. Airblast was determined at several ranges from the explosion, both axially and perpendicular to the row. Very few airblast stations were positioned within the cylindrical wave region. These data are presented in Figure 4 where the range is scaled by the square root of the linear explosive mass density. Data in the spherical wave region, i.e., at distances greater than the row length, are presented in Figure 5 where the range is scaled by the cube root of the total charge mass.

19. Because of the limited data in the cylindrical region of interest, an upper bound curve was extrapolated at an attenuation of the -0.6 power of the range. This exponent $(-0.6)$ was chosen to be half of the attenuation noted in the spherical region of -1.2 power of the range--the factor of one-half can be justified by theoretical considerations based on the geometry of the wave divergence.

20. Based on this extrapolation, a "safe" limit of 0.06 psi is expected at a scaled range of

$$
\mathrm{R} / \mathrm{w}^{1 / 2} \sim 325 \mathrm{ft} /(\mathrm{bb} / \mathrm{ft})^{1 / 2}
$$



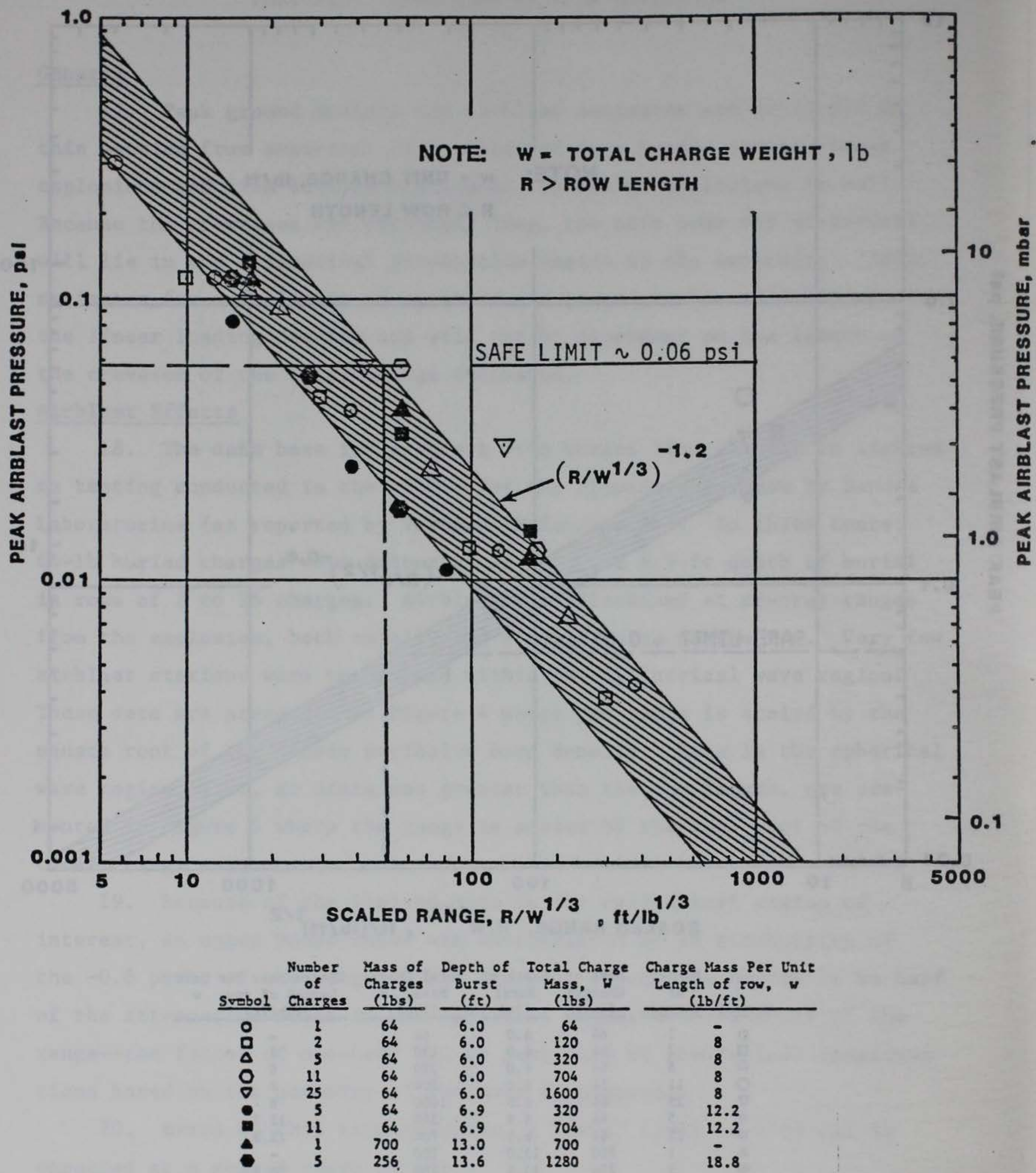

Figure 5. Peak airblast pressure from buried single and buried row charges 
Thus for linear charge density $w$ of $22.5 \mathrm{lb} / \mathrm{ft}$, a distance of

$$
R=325 \times(22.5)^{1 / 2}=1540 \mathrm{ft} \text {, say } 1600 \mathrm{ft}
$$

should be safe for airblast damage to windows for either crevasse. This distance should be considered as the closest distance to the levee.

21. An extremely conservative estimate can be made by lumping all explosives into a single point charge $W$ and using Figure 5 to estimate a safe distance. This approach will give a scaled range of

$$
\mathrm{R} / \mathrm{W}^{1 / 3} \sim 50 \mathrm{ft} /(1 \mathrm{~b})^{1 / 3}
$$

Then for Crevasse No. 1

$$
R \sim 50 \times(256,000)^{1 / 3}=3175 \mathrm{ft}
$$

while for Crevasse No. 2

$$
\mathrm{R} \sim 50 \mathrm{x}(135,000)^{1 / 3}=2560 \mathrm{ft}
$$

Ground Motions

22. Ground motion data from row charges in soil is limited to testing conducted by WES for the MEACE program and row charge tests at the WES Big Black Test Site. These data are unpublished (Reference 9). Briefly, ground motions were measured axially and along the perpendicular bisector to the row. The number of charges varied from 6 to 12 and the spacing and depth of burst were also varied. Linear charge densities varied from 4 to $18 \mathrm{lb} / \mathrm{ft}$.

23. Unfortunately, only a few of the measurements fell within the cylindrical wave region. Peak particle velocity data in the region less than the length of the row are shown in Figure 6 plotted versus the range scaled as the square root of the linear charge density. An upper bound curve was fitted with an attenuation with range to the -1.15 power (again half of the spherical wave coefficient). Data within the spherical region are shown in Figure 7 , where the peak particle velocity is plotted versus the range scaled to the cube root of the total charge mass. 


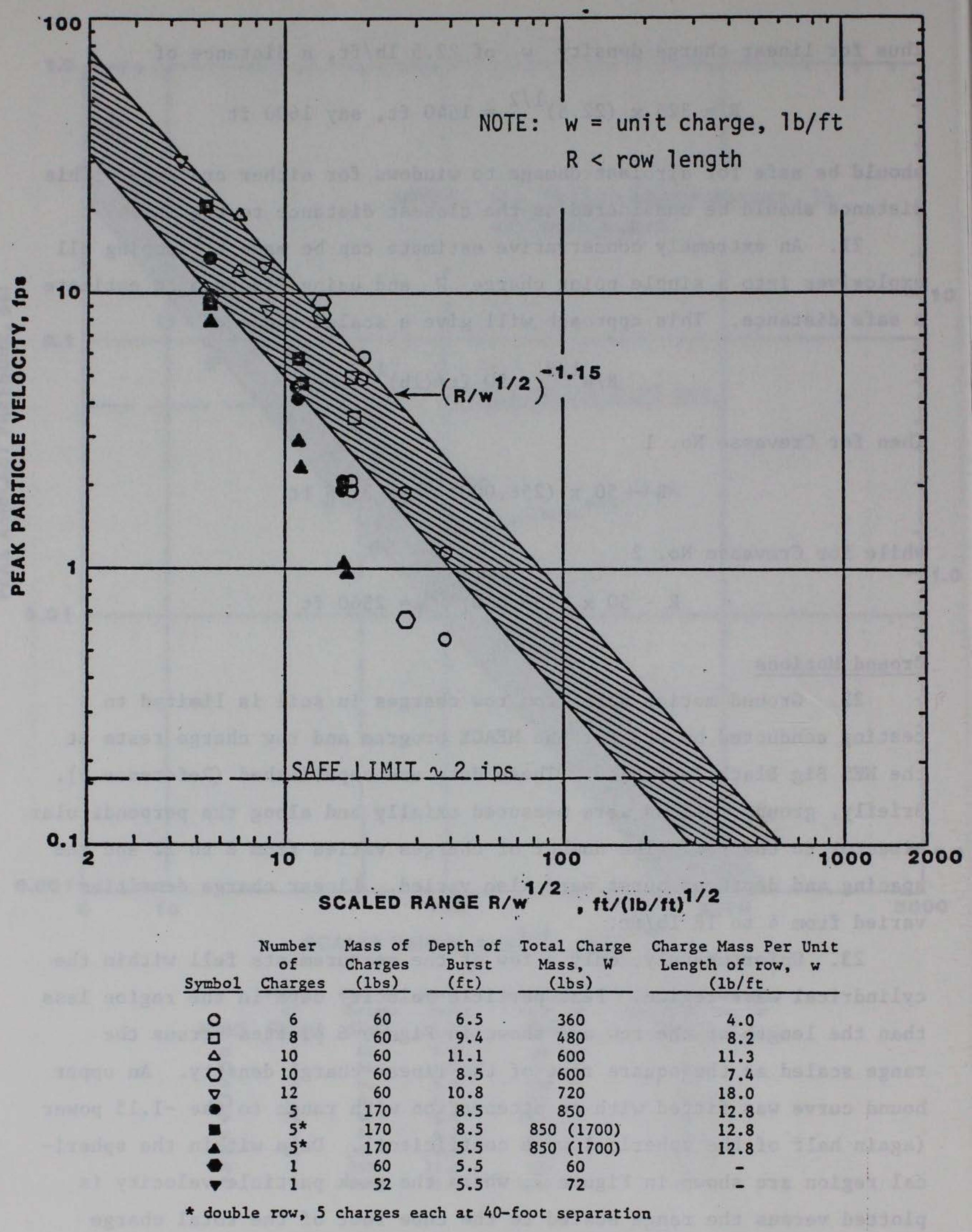

Figure 6. Peak particle motion from row charges scaled (square-root) as a line or cylindrical charge 


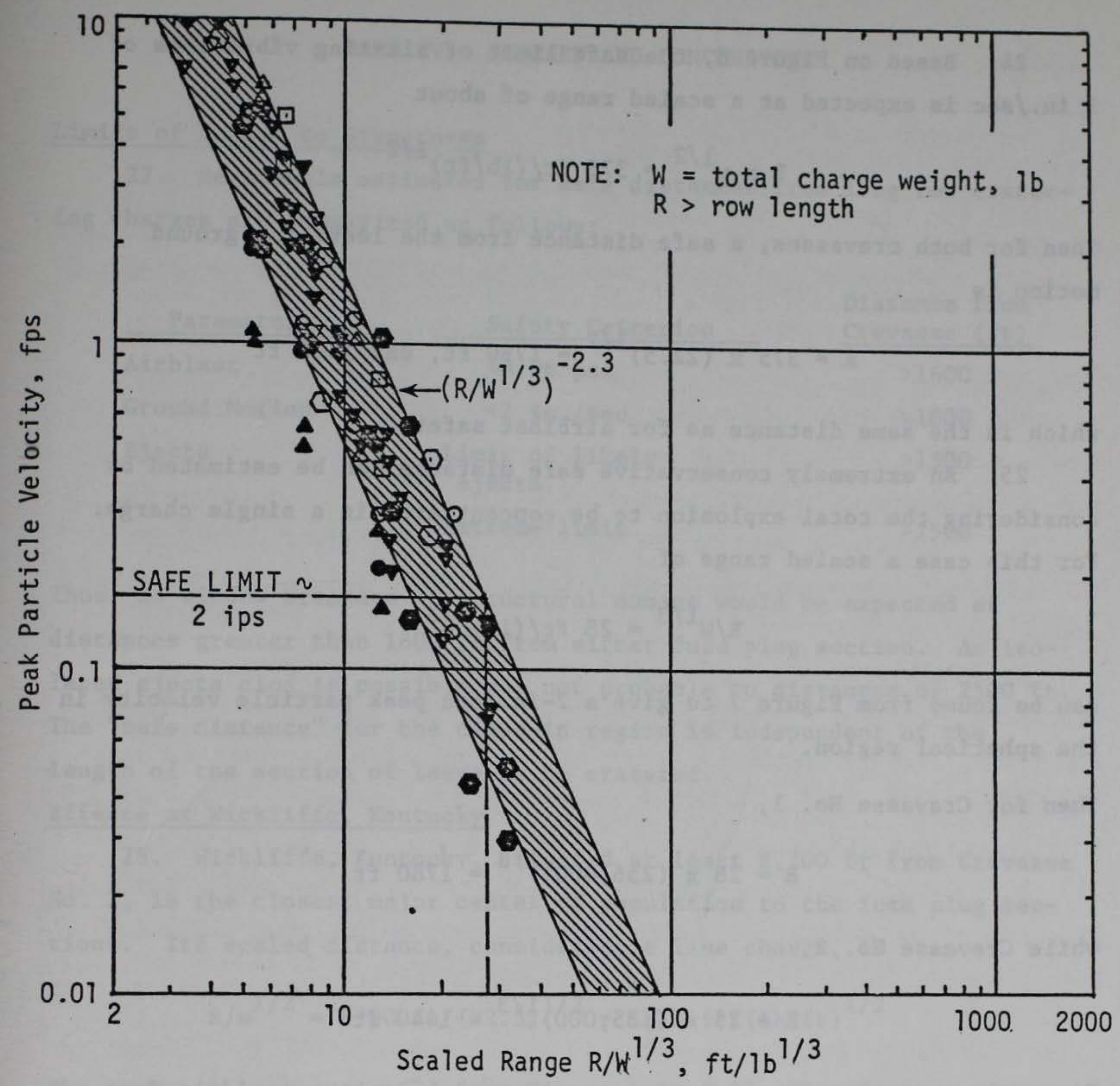

\begin{tabular}{|c|c|c|c|c|c|c|}
\hline Symbol & $\begin{array}{l}\text { Number } \\
\text { of } \\
\text { Charges }\end{array}$ & $\begin{array}{l}\text { Mass of } \\
\text { Charges } \\
\text { (1bs) }\end{array}$ & $\begin{array}{c}\text { Depth of } \\
\text { Burst } \\
\text { (ft) }\end{array}$ & $\begin{array}{c}\text { Total Charge } \\
\text { Mass, W } \\
\text { (1bs) }\end{array}$ & $\begin{array}{c}\text { Charge Mass Per } \\
\text { Length of row, } \\
(1 \mathrm{~b} / \mathrm{ft}\end{array}$ & $\begin{array}{l}\text { Untt } \\
w\end{array}$ \\
\hline 0 & 6 & 60 & 6.5 & 360 & 4.0 & \\
\hline 0 & 8 & 60 & 9.4 & 480 & 8.2 & \\
\hline$\Delta$ & 10 & 60 & 11.1 & 600 & 11.3 & \\
\hline 0 & 10 & 60 & 8.5 & 600 & 7.4 & \\
\hline$\nabla$ & 12 & 60 & 10.8 & 720 & 18.0 & \\
\hline - & 5 & 170 & 8.5 & 850 & 12.8 & \\
\hline 口 & $5 *$ & 170 & 8.5 & $850(1700)$ & 12.8 & \\
\hline$\Delta$ & $5^{*}$ & 170 & 5.5 & $850(1700)$ & 12.8 & \\
\hline & 1 & 60 & 5.5 & 60 & - & \\
\hline$\nabla$ & 1 & 52 & 5.5 & 72 & - & \\
\hline
\end{tabular}

Figure 7. Peak particle motion from buried single and buried row charges 
24. Based on Figure 6 , the safe limit of blasting vibrations of $2 \mathrm{in./sec}$ is expected at a scaled range of about

$$
R \times w^{1 / 2}=375 \mathrm{ft} /(1 \mathrm{~b} / \mathrm{ft})^{1 / 2}
$$

Then for both crevasses, a safe distance from the leeve for ground motion is

$$
R=375 \times(22.5)^{1 / 2}=1780 \mathrm{ft} \text {, say } 1800 \mathrm{ft}
$$

which is the same distance as for airblast safety.

25. An extremely conservative safe distance can be estimated by considering the total explosion to be concentrated in a single charge. For this case a scaled range of

$$
\mathrm{R} / \mathrm{W}^{1 / 3}=28 \mathrm{ft} /(\mathrm{lb})^{1 / 3}
$$

can be found from Figure 7 to give a $2-i n . / s e c$ peak particle velocity in the spherical region.

Then for Crevasse No. 1,

$$
R=28 \times(256,000)^{1 / 3}=1780 \mathrm{ft}
$$

while Crevasse No. 2,

$$
R=28 \times(135,000)^{1 / 3}=1440 \mathrm{ft}
$$

Ejecta

26. Limited ejecta measurements from row charges would place the limit of the ejecta to be about $1500 \mathrm{ft}$ with a very small probability of a clod extending to $2500 \mathrm{ft}$. 
PART IV: SUMMARY AND CONCLUSIONS

\section{Limits of Damage to Structures}

27. Reasonable estimates for safe distances from long row cratering charges are summarized as follows:

\begin{tabular}{|c|c|c|}
\hline Parameter & Safety Criterion & $\begin{array}{l}\text { Distance from } \\
\text { Crevasse (ft) } \\
\end{array}$ \\
\hline Airblast & $<0.06 \mathrm{psi}$ & $>1600$ \\
\hline Ground Motion & $<2$ in. $/ \mathrm{sec}$ & $>1800$ \\
\hline \multirow[t]{2}{*}{ Ejecta } & $\begin{array}{l}\text { Limit of likely } \\
\text { ejecta }\end{array}$ & $>1500$ \\
\hline & Extreme limit & $>2500$ \\
\hline
\end{tabular}

Thus, no window breakage or structural damage would be expected at distances greater than $1800 \mathrm{ft}$ from either fuze plug section. An isolated ejecta clod is possible but not probable to distances of $2500 \mathrm{ft}$. The "safe distance" for the close-in region is independent of the length of the section of leeve to be cratered.

Effects at Wickliffe, Kentucky

28. Wickliffe, Kentucky, situated at least $8,700 \mathrm{ft}$ from Crevasse No. 2, is the closest major center of population to the fuze plug sections. Its scaled distance, considering a line charge, is

$$
\mathrm{R} / \mathrm{w}^{1 / 2}=8700 \mathrm{ft} /(22.5)^{1 / 2}=1840 \mathrm{ft} /(1 \mathrm{~b} / \mathrm{ft})^{1 / 2}
$$

The peak airblast estimated from Figure 4 is 0.02 psi and the maximum particle velocity from Figure 6 is $0.35 \mathrm{in.} / \mathrm{sec}$.

29. Airblast is audible at amplitudes as low as 0.002 psi and can be considered loud and noticeable at 0.02 psi. Ground motion can be noticed by humans at $0.06 \mathrm{in./sec}$ and may be disturbing (but not harmful) at $0.4 \mathrm{in} . / \mathrm{sec}$.

Effects at Cairo, Illinois

30. Cairo, Illinois, is located about 3 miles north of Crevasse No. 1. Airblast and ground motions can be estimated from Figures 5 and 
7 because Cairo is in the spherical propagation region. Thus, the scaled distance is

$$
\mathrm{R} / \mathrm{W}^{1 / 3}=\frac{16,000 \mathrm{ft}}{(256,000 \mathrm{lb})^{1 / 3}} \sim 250 \mathrm{ft} / 1 \mathrm{~b}^{1 / 3}
$$

At this range the airblast is estimated to be 0.008 psi (barely audible). The predicted peak particle velocity is $0.001 \mathrm{in} / \mathrm{sec}$ which is below the level of human perception.

Conclusions

31. Structures should be safe beyond $1800 \mathrm{ft}$ from either explosion. Ejecta clods are possible but extremely unlikely to $2500 \mathrm{ft}$ and should pose no significant hazard to structures.

32. Safe limits will be the same for both crevasses. The limits are dependent only upon the linear loading density and not on the total charge mass detonated.

33. Wickliffe, Kentucky, will be safe. However, the explosion will be perceptible. Ground motions could be felt by humans and may be disturbing, but not harmful. Loose windows and doors may rattle, causing the explosion to be judged as severe by some residents in the area. Some complaints may be possible.

34. Cairo, Illinois, will not be affected by either explosion. It is likely that residents of Cairo will not hear or feel the explosion from Crevasse No. 1. No complaints are anticipated. 


\section{REFERENCES}

1. Emergency Employment of Army Resources, Appendix R to Supplement A to ER 500-1-1, Natural Disaster Procedures Under PL 84-99 Operation of Birds Point-New Madrid Floodway, MDR 500-1-1, Appendix R, U.S. Army Engineer District, Memphis, December 1979 (DRAFT).

2. Reed, Jack, "Predictions of Nuisance Damage and Hazard from Accidental Explosions During Trident Missile Test Flights, SAND 790626, Sandia Laboratories, March 1980.

3. Crande11, F.J., "Ground Vibration-Due to Blasting and Its Effects on Structures," Journal, Boston Society of Civil Engineers, April 1949.

4. Engineer Manual, EM 1110-2-3800, 1 March 1972, "Systematic Drilling and Blasting for Surface Excavations."

5. Nicholls, Harry R., et al., "Blasting Vibrations and Their Effects on Structures," U.S. Bureau of Mines Bulletin 656, 1971, Washington, D.C.

6. Medearis, Kenneth, "Blasting Vibration Damage Criteria for Low-Rise Structures," Sound and Vibration, Nov 1978.

7. A. J. Hendron, Jr., "Engineering of Rock Blasting on Civil Projects," pp. 242-277, in "Structural Geotechnical Mechanics, A Volume Honoring Nathan M. Newmark," ed W. J. Hall, Prentice-Hall Englewood Cliffs, N.J., 1977.

8. Vortman, Luke, "Airblast and Craters from Rows of Two to Twentyfive Buried HE Charges," SC-RR-68-655, Sandia Laboratories, Jan 1969.

9. Murre11, D. W., "Ground Motion Data from Row Charges," unpublished data, U.S. Army Engineer Waterways Experiment Station, CE, Vicksburg, Mississippi, March 1977.

10. Power, Dean V., "Intermediate Range Ground Motions for Pre-Gondola II and Associated Events," PNE-1115, Oct 1968, Lawrence Radiation Laboratory, Livermore, California.

11. Strange, J. N., et al., "Summary Report of the ESSEX Program, Vo1 I, Phenomology and Effects," U.S. Army Engineer Waterways Experiment Station, CE, Vicksburg, Mississippi.

12. American National Standards Institute, Committee on Mechanical Vibration and Shock, S-2; Working Group, Atmospheric Blast Effects, S-2-54, Standard for Single Point Explosions in Air; Draft Report; 20 July 1976. 